University of Nebraska - Lincoln

DigitalCommons@University of Nebraska - Lincoln

Faculty Papers and Publications in Animal

Science

Animal Science Department

January 1978

\title{
ESTIMATION OF HERITABILITIES FOR WEIGHT, HEIGHT AND FRONT CANNON BONE CIRCUMFERENCE OF THOROUGHBREDS
}

\author{
R. L. Hintz \\ Oklahoma State University, Stillwater \\ H. F. Hintz \\ Cornell University \\ L. Dale Van Vleck \\ University of Nebraska-Lincoln, dvan-vleck1@unl.edu
}

Follow this and additional works at: https://digitalcommons.unl.edu/animalscifacpub

Part of the Animal Sciences Commons

Hintz, R. L.; Hintz, H. F.; and Van Vleck, L. Dale, "ESTIMATION OF HERITABILITIES FOR WEIGHT, HEIGHT AND FRONT CANNON BONE CIRCUMFERENCE OF THOROUGHBREDS" (1978). Faculty Papers and Publications in Animal Science. 335.

https://digitalcommons.unl.edu/animalscifacpub/335

This Article is brought to you for free and open access by the Animal Science Department at DigitalCommons@University of Nebraska - Lincoln. It has been accepted for inclusion in Faculty Papers and Publications in Animal Science by an authorized administrator of DigitalCommons@University of Nebraska - Lincoln. 


\title{
ESTIMATION OF HERITABILITIES FOR WEIGHT, HEIGHT AND FRONT CANNON BONE CIRCUMFERENCE OF THOROUGHBREDS
}

\author{
R. L. Hintz ${ }^{1}$, H. F. Hintz and L. D. Van Vleck \\ Cornell University ${ }^{2}$, Itbaca, NY 14853
}

\section{SUMMARY}

A total of 19,833 records on 1,992 Thoroughbred foals out of 813 dams and by 365 sires was used to estimate heritability of weight, height at withers, and front cannon bone circumference. Measurement ages ranged from 0 to 174 days. Records were adjusted for the fixed effects of age of dam, sex of foal, and month and year of birth of the foal. Body weight, height at withers and front cannon bone circumference tended to be rather lowly heritable during the first few months but were moderately to strongly heritable by 1 year of age.

(Key Words: Growth, Heritability, Horses, Thoroughbreds.)

\section{INTRODUCTION}

Few estimates of heritability of weight in young horses are available. Furthermore, few studies have been reported in which the growth rates of large numbers of horses have been examined. This study was initiated to analyze the records obtained from a Thoroughbred farm in order to determine the effects of age of dam, sex of foal, month and year of birth, and genetic effect of sire on measurements of growth and to estimate a growth curve.

Knowledge of the relative amount of variation due to random environmental and genetic effects (heritability) is necessary for the use of optimum procedures to estimate the effects of various factors on growth or on the growth curve. Heritability estimates are also required for optimal selection procedures if selection for growth is desired. The purpose of this paper is to report estimates of heritability for some

\footnotetext{
${ }^{1}$ Present address: Department of Animal Science, Oklahoma State University, Stillwater.

${ }^{2}$ Department of Animal Science.

${ }^{3}$ Oshawa, Ontario, Can.
}

growth characteristics of Thoroughbreds.

\section{MATERIALS AND METHODS}

Every foal at Windfields Farm $^{3}$ is weighed, and height at withers and cannon bone circumference at the midpoint are measured on about the 15 th of each month. A total of 19,833 records on 1,992 foals out of 813 dams and by 365 sires was collected from January 1958 to June 1976. Since the age at time of measurement ranged from 0 to 714 days, the records were classified into 47 age groups as described in table 1. The effects of sex of foal, age of dam and month-year of birth of foal were to be estimated as well as variances due to effects of sires (genetic values) and residual effects.

The following linear model was assumed for each growth measurement (weight, height, and front cannon bone):

$$
\underline{Y}=\underset{\sim}{X} \beta+\underset{\sim}{Z}+\underset{\sim}{e}
$$

where $Y$ is the vector of records; $\beta$ is a vector of sex of foal effects, age of dam effects, monthyear of birth of foal effects, age group effects and population mean; $\underset{\sim}{X}$ is a known design matrix; $\underset{\sim}{u}$ is a vector of one-half the additive genetic effects of the sires having a multivariate distribution with mean zero and nonsingular variance-covariance matrix $\mathrm{G} ; \underset{Z}{Z}$ is a known design matrix; $e$ is a vector of residual effects including environmental and other genetic effects having a multivariate distribution with mean zero and variance-covariance matrix $\underset{\sim}{\mathrm{R}}$; and $\underset{\mathrm{u}}{\mathrm{a}}$ and $\mathrm{e}$ are mutually uncorrelated.

It was assumed that $\underset{\sim}{\mathrm{R}}=\underset{\sim}{\mathrm{I}} \sigma_{e}^{2}$, where $\underset{\sim}{\mathrm{I}}$ is an identity matrix with order equal to the number of records, which implies that the elements of $\mathrm{e}$ are uncorrelated and that all records have common variance, $\sigma_{e}^{2}$. The variance-covariance matrix, $\mathrm{G}$, is the matrix of variances and covariances of the sire effects.

Since the sire and error variances are not likely to be the same for all age groups, the data 1243 
TABLE 1. GROUPING OF RECORDS BY AGE OF FOALS AT TIME OF MEASUREMENT INTO 47 AGE GROUPS AND NINE SECTIONS ${ }^{a}$

\begin{tabular}{llllll}
\hline $\begin{array}{l}\text { Age } \\
\text { group }\end{array}$ & $\begin{array}{l}\text { Age of } \\
\text { foals } \\
\text { (days) }\end{array}$ & $\begin{array}{l}\text { Age } \\
\text { group }\end{array}$ & $\begin{array}{l}\text { Age of } \\
\text { foals } \\
\text { (days) }\end{array}$ & $\begin{array}{l}\text { Age } \\
\text { group }\end{array}$ & $\begin{array}{l}\text { Age of } \\
\text { foals } \\
\text { (days) }\end{array}$ \\
\hline 1 & $0-4$ & 17 & $80-84$ & 33 & $300-314$ \\
2 & $5-9$ & 18 & $85-89$ & 34 & $315-329$ \\
3 & $10-14$ & 19 & $90-104$ & 35 & $330-344$ \\
4 & $15-19$ & 20 & $105-119$ & 36 & $345-359$ \\
5 & $20-24$ & 21 & $120-134$ & 37 & $360-389$ \\
6 & $25-29$ & 22 & $135-149$ & 38 & $390-419$ \\
7 & $30-34$ & 23 & $150-164$ & 39 & $420-449$ \\
8 & $35-39$ & 24 & $165-179$ & 40 & $450-479$ \\
9 & $40-44$ & 25 & $180-194$ & 41 & $480-509$ \\
10 & $45-49$ & 26 & $195-209$ & 42 & $510-539$ \\
11 & $50-54$ & 27 & $210-224$ & 43 & $540-569$ \\
12 & $55-59$ & 28 & $225-239$ & 44 & $570-599$ \\
13 & $60-64$ & 29 & $240-254$ & 45 & $600-629$ \\
14 & $65-69$ & 30 & $255-269$ & 46 & $630-659$ \\
15 & $70-74$ & 31 & $270-284$ & 47 & $660-714$ \\
16 & $75-79$ & 32 & $285-299$ & & \\
\hline
\end{tabular}

${ }^{a}$ The horizontal lines indicate the division of age groups into sections. For example, section 1 includes age groups 1 through 9 .

shown in table 1 . The sire and error variances then were assumed to be homogeneous for measurements at all ages within a section of the data. The variance-covariance matrix, $G$, was assumed to be $I \sigma_{s}^{2}$, where $I$ is an identity matrix with order equal to the number of sires in a section. Henderson's Method 2 is accomplished by estimating the fixed and random effects as if the random effects were fixed for computational purposes only, then adjusting the data with estimates of the fixed effects. Henderson's Method 1 is then applied to the corrected data, making adjustments in the coefficients of $\sigma_{e}^{2}$ in the expectations of the quadratic forms. Henderson's Method 1 is a procedure for estimating variance components for a completely random model where expectations are equated to the corresponding quadratic forms.

Heritabilities were estimated for the three growth measurements for each of the nine sections by:

$$
\hat{h}^{2}=4 \hat{\sigma}_{s}^{2} /\left(\hat{\sigma}_{s}^{2}+\hat{\sigma}_{e}^{2}\right)
$$

Sampling variances of the variance components were not computed because of the amount of computer time required and because the sampling variances are functions of the unknown variances which were being estimated. However, approximate standard deviations of the heritability estimates were calculated using an approximate formula (Swiger et al., 1964).

\section{RESULTS AND DISCUSSION}

The heritability estimates and their standard errors are listed in table 2. The heritability estimates for weight of the older age groups of foals were higher than estimates previously reported, which are shown in table 3. Previous estimates were primarily from records of 2-year-old or older animals except for the work of Kownacki et al. (1971) which included suckling foals. Heritability estimates for weight except for the one from the oldest age group are similar to estimates for young beef cattle (Petty and Cartwright, 1966). The reason for the high estimate for the oldest age group is

TABLE 2. HERITABILITY ESTIMATES OF WEIGHT, HEIGHT AT WITHERS AND FRONT CANNON BONE CIRCUMFERENCE AND THEIR STANDARD ERRORS

\begin{tabular}{rlllllll}
$\begin{array}{l}\text { Range of } \\
\text { age } \\
\text { (days) }\end{array}$ & $\begin{array}{l}\text { No. of } \\
\text { foals }\end{array}$ & $\begin{array}{l}\text { No. of } \\
\text { records }\end{array}$ & $\begin{array}{l}\text { Avg age } \\
\text { of foals } \\
\text { (days) }\end{array}$ & $\begin{array}{l}\text { No. of } \\
\text { sires }\end{array}$ & Weight & $\begin{array}{l}\text { Height at } \\
\text { withers }\end{array}$ & $\begin{array}{l}\text { Cannon bone } \\
\text { circumference }\end{array}$ \\
\hline $0-44$ & 1513 & 1945 & 22.3 & 283 & $.21 \pm .03$ & $.33 \pm .04$ & $.17 \pm .03$ \\
$45-89$ & 1298 & 1702 & 66.4 & 349 & $.13 \pm .04$ & $.45 \pm .05$ & $.12 \pm .04$ \\
$90-149$ & 1198 & 2080 & 118.4 & 183 & $.47 \pm .04$ & $.57 \pm .04$ & $.16 \pm .03$ \\
$150-209$ & 1217 & 2164 & 178.3 & 151 & $.45 \pm .04$ & $.49 \pm .04$ & $.25 \pm .03$ \\
$210-269$ & 1216 & 2226 & 238.8 & 138 & $.55 \pm .04$ & $.65 \pm .05$ & $.43 \pm .04$ \\
$270-329$ & 1210 & 2301 & 298.9 & 133 & $.62 \pm .04$ & $.69 \pm .05$ & $.44 \pm .04$ \\
$330-389$ & 1185 & 2178 & 358.2 & 132 & $.60 \pm .04$ & $.72 \pm .05$ & $.52 \pm .04$ \\
$390-449$ & 944 & 2028 & 418.7 & 126 & $.50 \pm .04$ & $.54 \pm .04$ & $.50 \pm .04$ \\
$450-714$ & 1114 & 3209 & 509.9 & 165 & $.90 \pm .05$ & $.88 \pm .05$ & $.77 \pm .04$ \\
\hline
\end{tabular}


TABLE 3. REPORTED HERITABILITY ESTIMATES OF WEIGHT, HEIGHT AT WITHERS AND FRONT CANNON BONE CIRCUMFERENCE

\begin{tabular}{llll} 
Estimates adapted from & Weight & $\begin{array}{l}\text { Height } \\
\text { at withers }\end{array}$ & $\begin{array}{l}\text { Cannon bone } \\
\text { circumference }\end{array}$ \\
\hline Dusek (1965) & .27 & .63 & .28 \\
Varo (1965) & $.16-.38$ & $.17-.34$ & $. .14-.31$ \\
Ericksson (1971) & $\ldots$. & $.29, .41$ & $.48, .53$ \\
Khotov (1971) & $\ldots$. & .42 & .25 \\
Kownacki et al. (1971) & $.12, .48$ & $.52, .78$ & $.53, .78$ \\
Kalmykov (1973) & $\ldots$. & $.38-.82$ & $. .28-. .56$ \\
Barauskas (1974) & $\ldots$ & .99 & .13 \\
Kalmykov (1974) & $\ldots$ & $.38-.68$ & $.24-.50$ \\
\hline
\end{tabular}

${ }^{\text {a }}$ Cited by Jones and Bogart (1971)!

unknown, although this was, however, the group with the largest range of ages.

Estimates of heritability for height at withers and front cannon bone circumference are rather high but are within the range of previously reported estimates (table 3 ). The trend for heritability of growth measurements to increase with increasing age has been shown previously in horses (Kownacki et al., 1971) and in beef cattle (Petty and Cartwright, 1966).

The appropriate ratios of error variance to sire variance obtained from this study were used in statistical estimation of effects of sex of foal, age of dam, month-year of birth of foal and growth curves which will be presented elsewhere.

\section{CONCLUSIONS}

The rather high heritability estimates obtained indicate that genetic change for weight, height at withers, and front cannon bone circumference could be accomplished if selection for these growth measurements is desired. With the knowledge of the relative amount of variation due to random environmental and genetic effects, optimum procedures can be used to estimate the effects of various factors on growth.

\section{LITERATURE CITED}

Barauskas, V. 1974. Investigation of the inheritance of some characters in Zemaitukai ponies. Lietuvous Veterinarijos Akademijos Darbai. 10:323. (Anim. Breed. Abstr. 43:2:36).

Dusek, J. 1965. The heritability of some characters in the horse. Zivocisna Vyroba. 10:449. (Anim. Breed. Abstr, 33:4:532).

Henderson, C. R. 1953. Estimation of variance and covariance components. Biometrics 9:226.

Jones, W. E. and R. Bogart. 1971. Genetics of the Horse. Edwards Brothers, Inc., Ann Arbor, MI.

Kalmykov, A. N. 1973. Heritability of economic traits in the Orlov Trotter. Genetika. 9:8:50. (Anim. Breed. Abstr. 42:1:3).

Kalmykov, A. N. 1974. The selection of Orlov Trotters for body measurements. Uchenye Zapiski Kazanskogo Gosundarstvennogo Veterinarnogo Instituta. 116:158. (Anim. Breed. Abstr. 44:3:120).

Khotov, V. 1971. Progeny testing of purebred AngloKarachaev saddle stallions. Doklady TSKhA. (Anim. Breed. Abstr. 42:7:297).

Kownacki, M., M. Fabiani and K. Jaszczak. 1971. Genetical parameters of some traits of thoroughbred horses. Genetica Polonica. 12:4:431.

Petty Jr., R. R. and T. C. Cartwright, 1966. A summary of genetic and environmental statistics for growth and conformation traits of young beef cattle. Anim. Sci. Dept. Technical Rep. \#5, Texas A \& M University, Texas Agr. Exp. Sta.

Swiger, L. A., W. R. Harvey, D. O. Everson and K. E. Gregory. 1964. The variance of intraclass correlation involving groups with one observation. Biometrics 20:818.

Varo, M. 1965. Some coefficients of heritability in horses. Annales Agriculturae Fenniae 4:223. 